\title{
Relationship between udder measurements during pregnancy and . partial daily milk yield in goats
}

\author{
I. J. James and O. A. Osinowo \\ Department of Animal Breeding and Genetics, University of Agriculture, Abeokuta, Nigeria
}

\begin{abstract}
Relationship between udder measurements during pregnancy and partial daily milk yield (PDM) in ten West African Dwarf (WAD), three Red Sokoto (RS) and Sahel goats was studied. Udder width $(U W)$, udder circumference (UC), distance between teats (DBT) and teat length (TL) were measured monthly before conception and during pregnancy up to parturition. PDM was determined weekly for 12 weeks of lactation commencing from 4 days post partum. There was a slight increase in udder dimensions within the first 2 trimesters of pregnancy (day $0-100$ ) and then followed by an exponential increase during the third trimester (last 50 days of pregnancy) across the breeds. Sahel does had the largest udder dimensions with highest average PDM while WAD does had the smallest udder with lowest average PDM. The highest correlations between udder growth curve parameters and average PDM were obtained with $A(r \quad 0.795)$ and $b(r=0.609)$. Thus, udder size at conception and during pregnancy appeared to be a significant determinant of average PDM per lactation and could be more important to average PDM than the rate of increase in udder size during pregnancy.
\end{abstract}

Key words: Udder measurements, pregnancy, trimester, lactation, partial daily milk yield

\section{Introduction}

Changes in udder dimensions during pregnancy have been attributed to extensive proliferation of cells in the mammary gland, associated with endocrine activities (Anderson et al., 1981; Dijkstra et al., 1997). The pattern of udder changes in goats has been studied quantitatively for many years using descriptors such as wet weight, dry fat-free tissue (DFFT) and DNA content (Tucker, 1987). However, udder width (UW), udder circumference (UC), distance between teats (DBT) and teat length (TL) are used in this study as recommended by James (2000).
Udder biometrics is related to milk yield in goats. Milk, which has great nutritional significance to both humans and livestock is synthesized and secreted by the epithelial cells lining the alveoli of the mammary gland (Singh et al., 1993). The apposition of pairs of mammary glands forms an udder. Since the size of udder largely reflects milk secretion capacity while cell population is a crucial determinant of milk yield (Dijkstra et al., 1997), hyper plastic growth of the mammary gland is of particular interest. The objective of this research is to study changes in udder dimensions of WAD, RS and Sahel goats during pregnancy and to determine their relationship with average PDM. 


\section{James and Osinowo}

\section{Materials and Methods}

\section{Animals' management and experimental} procedure

The study was conducted at the University of Agriculture, Abcokuta, Sonth-Western Nigeria, located within the humid zone. Ten WAD, three RS and threc Sahel does weighing between 14 $23 \mathrm{~kg}$ were used for the study. They were managed semi-intensively. The udder dimensions measured before and during pregnancy by a fexible canvas tape-rule were udder width (UW). udder circumference (UC), distance between tcals (DBT) and teat length (TL) as shown in figure 1. UW was taken as the distance between the widest points of the udder, $\mathrm{UC}$ as the distance (perimeter) round the widest point of the udder, DBT as the distance between the two teat tips and $T L$ as the distance

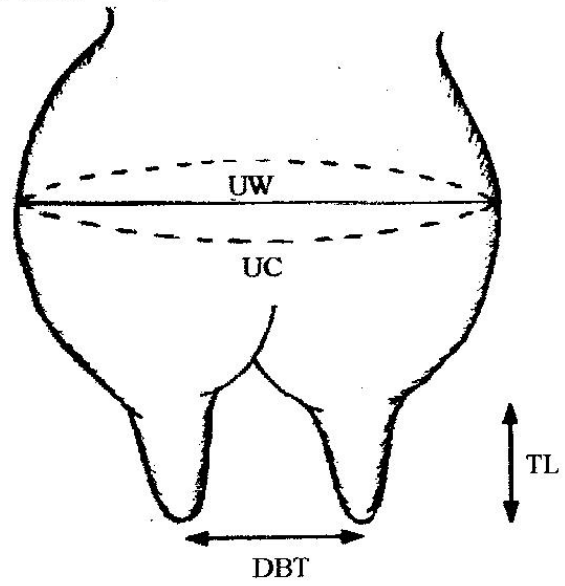

Figure 1 Udder measurements in goats

Key

UW Udder width

UC Udder circumference

DBT Distance between teats

TL Teat length

between teat tip and base of attachment to the udder. The udder dimensions were measured for three months prior to pregnancy. The frequency of data collection was monthly prior to and during pregnancy except during lactation when milk yield was measured weekly for 12 weeks commencing from 4 days post partum. On the evening preceding milking, the kids were separated from their dams overnight (for 12 hours) and the does were hand-milked the following morning. The milk yield obtained was defined as the partial daily milk yield (PDM), which is a combination of milk off-take and 12hour milk yield. All measurements were taken in the morning on the days of data collection before the animals were turned out to pasture or milked.

\section{Data analysis}

The data generated for each udder trait prior to and during pregnancy were plotied in a graph. Values for each trait were read-off the graph for day of conception (day 0), 50, 100 and 150 days of gestation. A gestation length of 150 days was assumed, enabling the retroactive determination of conception day given the day of parturition. Analysis of data was by methods of least squares (Systat, 1993), using the model:

$Y_{i j k} \quad=\mu+B_{i}+D_{j}+B D_{i j}+E_{i j k}$

where

$\mathrm{Y}_{\mathrm{ij}}=$ The value of the trait of interest

$\mu=$ The overall mean of the trait of interest

$B_{i}=$ The fixed effect of the $i^{\text {th }}$ breed $(i=1-3)$

$D_{j}=$ The fixed effect of $j^{\text {th }}$ day of gestation $(\mathrm{j}=1-4)$

$\mathrm{BD}_{\mathrm{ij}}=$ The interaction between breed and day of gestation

$E_{i \mathrm{k}}=$ Random error associated with each record (which is normally,independently and identically distributed with zero mean and variance.

The lactation data generated were analysed by methods of least squares (Systat, 1993), using the model:

$\mathrm{Y}_{\mathrm{j} j \mathrm{k}} \quad=\boldsymbol{\mu}+\mathrm{B}_{\mathrm{i}}+\mathrm{W}_{\mathrm{j}}+\mathrm{BW}_{\mathrm{ij}}+\mathrm{E}_{\mathrm{ijk}}$

Where

$Y_{\mathrm{ijk}}=$ The value of the trait of interest

$\mu=$ The overall mean of the trait of interest

$\mathrm{B}_{\mathrm{i}}=$ The fixed effect of the $\mathrm{i}^{\mathrm{th}}$ breed $(\mathrm{i}=1-3)$

$\mathrm{W}_{1}=$ The fixed effect of $\mathrm{j}^{\text {th }}$ week of lactation $(\mathrm{j}=1-12)$

$\mathrm{BW}_{\mathrm{ij}}=$ The interaction between breed and week of gestation 
$E_{i j k}=$ Random error associated with each record record (which is normally, independently and identically distributed with zero mean and variance).

Average partial daily milk yield for individual animal was also determined.

Significant differences between means of data generated during pregnancy and lactation were determined using Duncan's Multiple Range Test (Gomez and Gomez, 1984).

\section{Data adjustment}

In order to obtain phenotypic relationship between the udder traits studied, data were adjusted using constant estimates generated from the least squares analysis. The adjustment equation is :

$\gamma=\mathrm{Y}-\mathrm{b}_{\mathrm{i}}-\mathrm{d}_{\mathrm{j}}$

where

$\gamma=$ The adjusted udder trait

$\mathrm{Y}=$ The unadjusted udder trait

$b_{i}=$ The adjustment factor for the effect of the $i^{\text {th }}$ breed $(\mathrm{i}=1-3)$

$d_{j}=$ The adjustment factor for the effect of the $j^{\text {th }}$ day of gestation $(j=1-4)$

Also, to obtain the phenotypic correlations between udder growth curve parameters and average partial daily milk yield, data were adjusted using constant estimates generated from the least squares analysis. The adjustment equation was:

$\alpha=\beta-b_{i}$

where

$\alpha=$ The adjusted udder growth curve parameter

$\beta=$ The unadjusted udder growth curve parameter

$b_{i}=$ The adjustment factor for the effect of the $i^{\text {th }}$ breed $(\mathrm{i}=1-3)$

\section{Modeling of udder growth}

The udder circumference (UC) was selected as a measure of udder size. The variations in UC during pregnancy were modeled using an exponential equation by Anderson et al. (1981): $\mathrm{Y}=\mathrm{Ae}^{\mathrm{bX}}$

where

$\mathrm{Y}=$ The trait of interest to be modeled (UC)
$A=$ Constant term for the value of the trait of interest (UC)

$\mathrm{e}=$ Base of the natural logarithm

$\mathrm{b}=$ Constant term for the rate of growth of the trait of interest (UC)

$\mathrm{X}=$ Days of gestation.

The regressions were carried out by imputation of the equation into non-linear regression package (Systat, 1993) for the generation of parameters $\mathrm{A}$ and $\mathrm{b}$ for individual animals used. The parameters generated for each individual animal were subjected to least squares analysis (Systat. 1993) to determine the effect of breed on the udder growth curve parameters and average PDM. The statistical model uscd was:

$\mathrm{Y}_{\mathrm{ij}} \quad=\quad \mu+\mathrm{B}_{\mathrm{i}}+\mathrm{E}_{\mathrm{ijk}}$

where

$Y_{\mathrm{ijk}}=$ The value of the parameter

$\mu=$ The overall mean of the parameter

$B_{i}=$ The fixed effect of the $i^{\text {th }}$ breed $(i=1-3)$

$E_{\mathrm{ijk}}=$ Random error associated with each record

Significant differences between means were determined using Duncan's Multiple Range Test (Gomez and Gomez, 1984). Corrclation. between the udder growth curve parameters and average PDM were determined using Pearson correlation and Bonferroni probabilities (Systat. 1993).

\section{Results and Discussion}

The present study showed that Sahel does had the largest udder dimensions with highest average PDM while WAD does had the smallest udder dimensions with lowest PDM (Table 1 and 2). The finding is in consonance with the observation of Akpa et al. (1998) who reported significant influence of breed on udder size of WAD and RS goats. James (2000) asserted that heavy breeds possess larger udder size with higher average PDM than the lighter ones. The slight increase in dimensions of udder from conception to 2nd trimester of pregnancy and the exponential increase during the 3 rd trimester of pregnancy up to parturition corroborate the findings of Knight and Wilde (1993) which revealed that little mammary cell proliferation 


\section{James and Osinowo}

occurs in early pregnancy while substantial increase takes place during the last trimester of pregnancy when a doe is preparing for parturition and lactation. However, Dijkstra et al. (1997) attributed this mammary cell increases to endocrine activities associated with pregnancy that stimulate extensive cell proliferation in the mammary gland. The constant term for udder size (parameter A) of WAD goats was the least while Sahel goats had the highest value (Table 4). This is expected because WAD goats had the least udder dimensions while Sahel goats had the largest udder dimensions (Table 1).
This observation corroborates the finding of Amao (1999) which revealed that WAD goats had smaller udder size vis-à-vis Red Sokoto goats. This further explains why WAD goats had lowest PDM than the other two breeds (Table 3). James and Osinowo (2002) and James et al. (2002) have shown that udder size largely reflects milk production in goats. Also, Table 4 showed that the constant term for the rate of udder growth (parameter b) during pregnancy was highest in WAD goats than the other two breeds. This reveals that the rate of proliferation of milk-secreting cells in the udder of WAD goats is higher than the other two breeds thus suggesting a potential higher rate of milk production but is disadvantaged 


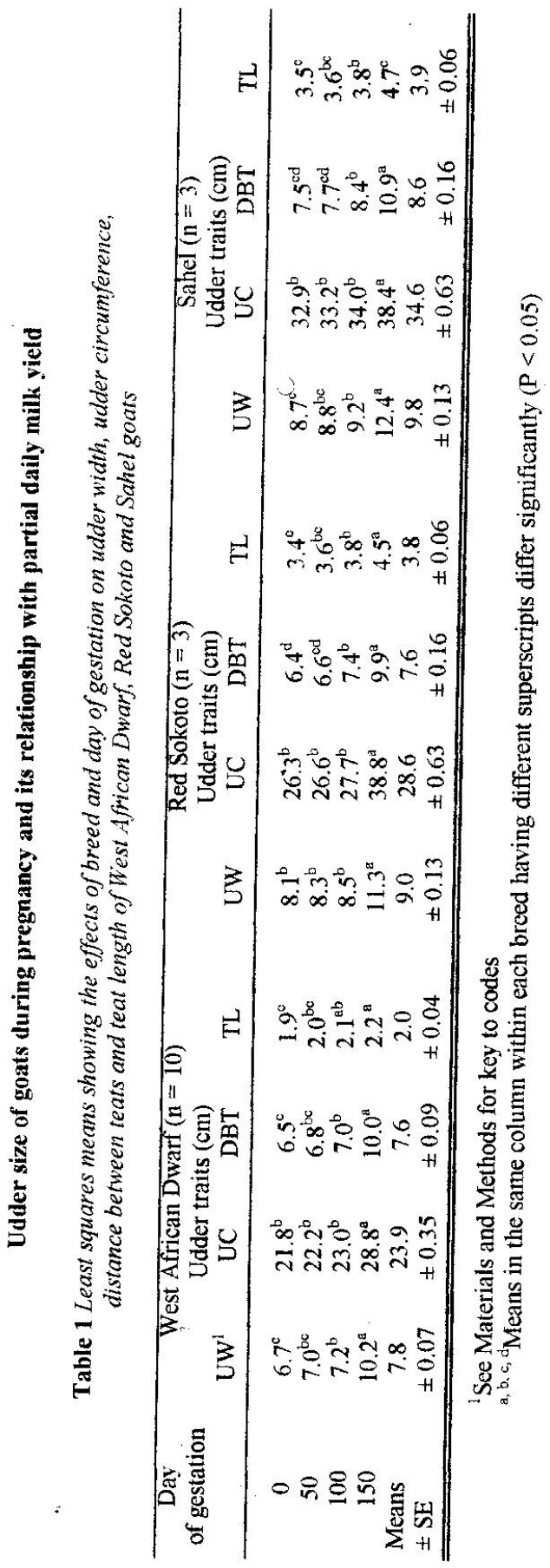




\section{James and Osinowo}

Table 2 Relative changes in the dimensions of udder traits of West African Dwarf, Red Sokoto and Sahel goats during pregnancy

\begin{tabular}{|c|c|c|c|c|c|c|}
\hline \multirow{4}{*}{$\begin{array}{l}\text { Udder } \\
\text { traits }\end{array}$} & \multicolumn{2}{|c|}{$\begin{array}{l}\text { West African Dwarf ( } \mathrm{n}= \\
10)\end{array}$} & \multicolumn{2}{|c|}{$\begin{array}{c}\text { Red Sokoto } \\
(\mathrm{n}=3)\end{array}$} & \multicolumn{2}{|c|}{$\begin{array}{l}\text { Sahel } \\
(\mathrm{n}=3)\end{array}$} \\
\hline & \multirow{2}{*}{\multicolumn{2}{|c|}{$\begin{array}{c}\% \text { Change during } \\
\text { pregnancy } \\
\text { Days of gestation }\end{array}$}} & \multirow{2}{*}{\multicolumn{2}{|c|}{$\begin{array}{l}\% \text { Change during } \\
\text { pregnancy } \\
\text { Days of gestation }\end{array}$}} & \multirow{2}{*}{\multicolumn{2}{|c|}{$\begin{array}{l}\text { \% Change during } \\
\text { pregnancy } \\
\text { Days of gestation }\end{array}$}} \\
\hline & & & & & & \\
\hline & $0-100$ & $100-150$ & $0-100$ & $100-150$ & $0-100$ & $100-150$ \\
\hline $\mathrm{UW}^{1}, \mathrm{~cm}$ & 7.4 & 41.7 & 4.9 & 32.9 & 5.7 & 42.5 \\
\hline $\mathrm{UC}, \mathrm{cm}$ & 5.5 & 25.2 & 5.3 & 22.0 & 3.3 & 12.9 \\
\hline DBT, cm & 6.5 & 42.9 & 15.6 & 33.8 & 12.0 & 29.8 \\
\hline $\mathrm{TL}, \mathrm{cm}$ & 10.5 & 4.8 & 11.8 & 18.4 & 8.6 & 23.7 \\
\hline
\end{tabular}

${ }^{1}$ See Materials and Methods for key to codes

Table 3 Least squares means showing the effects of breed and week of lactation on partial daily milk yield of West African Dwarf, Red Sokoto and Sahel goats

\begin{tabular}{|c|c|c|c|}
\hline Week of lactation & $\begin{array}{l}\text { West African Dwarf } \\
\qquad(n=10) \\
\text { Partial daily milk yield }\end{array}$ & $\begin{array}{c}\text { Red Sokoto } \\
(n=3) \\
\text { Partial daily milk yield }\end{array}$ & $\begin{array}{c}\text { Sahel } \\
(\mathbf{n}=3)\end{array}$ \\
\hline 1 & $179.4^{\mathrm{b}}$ & $226.0^{\mathrm{b}}$ & $246.7^{b}$ \\
\hline 2 & $185.5^{\mathrm{ab}}$ & $234.7^{a}$ & $256.0^{\mathrm{a}}$ \\
\hline 3 & $190.8^{\mathrm{c}}$ & $198.0^{c}$ & $188.9^{c}$ \\
\hline 4 & $151.4^{\mathrm{c}}$ & $168.7^{\mathrm{d}}$ & $165.0^{\mathrm{d}}$ \\
\hline 5 & $131.3^{\mathrm{d}}$ & $150.0^{\mathrm{e}}$ & $153.0^{\mathrm{e}}$ \\
\hline 6 & $115.6^{e}$ & $135.3^{\mathrm{f}}$ & $144.0^{f}$ \\
\hline 7 & $106.9^{f}$ & $125.3^{\mathrm{g}}$ & $125.0^{\mathrm{g}}$ \\
\hline 8 & $91.0^{\mathrm{g}}$ & $118.7^{\mathrm{g}}$ & $115.0^{8}$ \\
\hline 9 & $79.5^{h}$ & $105.7^{\mathrm{h}}$ & $109.3^{\text {f }}$ \\
\hline 10 & $71.7^{i}$ & $95.7^{\mathrm{i}}$ & $104.3^{\mathrm{hi}}$ \\
\hline 11 & $64.0^{\mathrm{j}}$ & $86.7^{\mathrm{ij}}$ & $98.7^{\mathrm{ij}}$ \\
\hline 12 & $57.3^{\mathrm{k}}$ & $78.0^{\mathrm{j}}$ & $95.3^{\mathrm{j}}$ \\
\hline Means $\pm \mathrm{SE}$ & $118.7 \pm 1.12^{3}$ & $142.5 \pm 2.04^{2}$ & $150.9 \pm 2.04^{1}$ \\
\hline
\end{tabular}

\footnotetext{
${ }^{a-k}$ Means in the same column having different superscript letters differ significantly $(\mathrm{P}<0.05)$

$1,2,3$ Means across breeds having different superscript numbers differ significantly $(\mathrm{P}<0.05)$
} 
Udder size of goats during pregnancy and its relationship with partial daily milk yield

Table 4 Least squares means $( \pm S E)$ showing the effect of breed on udder growth curve parameters and average partial daily milk yield of West African Dwarf, Red Sokoto and Sahel goats.

\begin{tabular}{lcccc} 
Breed & $\mathrm{N}$ & $\frac{\text { Udder growth curve parameters and average partial daily milk yield }}{\mathrm{A}}$ & $\mathrm{B}$ & PDM (m) \\
$\begin{array}{l}\text { West } \\
\begin{array}{l}\text { African } \\
\text { Dwarf }\end{array}\end{array}$ & 10 & $20.517 \pm 0.76^{\mathrm{c}}$ & $0.00164 \pm 0.00007^{\mathrm{b}}$ & $118.7 \pm 2.78^{\mathrm{c}}$ \\
Red Sokoto & 3 & $25.270 \pm 1.39^{\mathrm{b}}$ & $0.00119 \pm 0.00013^{\mathrm{a}}$ & $142.5 \pm 5.08^{\prime \prime}$ \\
Sahel & 3 & $32.067 \pm 1.39^{\mathrm{a}}$ & $0.00080 \pm 0.00013^{\mathrm{a}}$ & $150.9 \pm 5.08^{\prime}$ \\
\hline
\end{tabular}

a,b,c Means in the same column followed by different superscript letters differ significantly
$(P<0.05)$

"Average partial daily milk yield

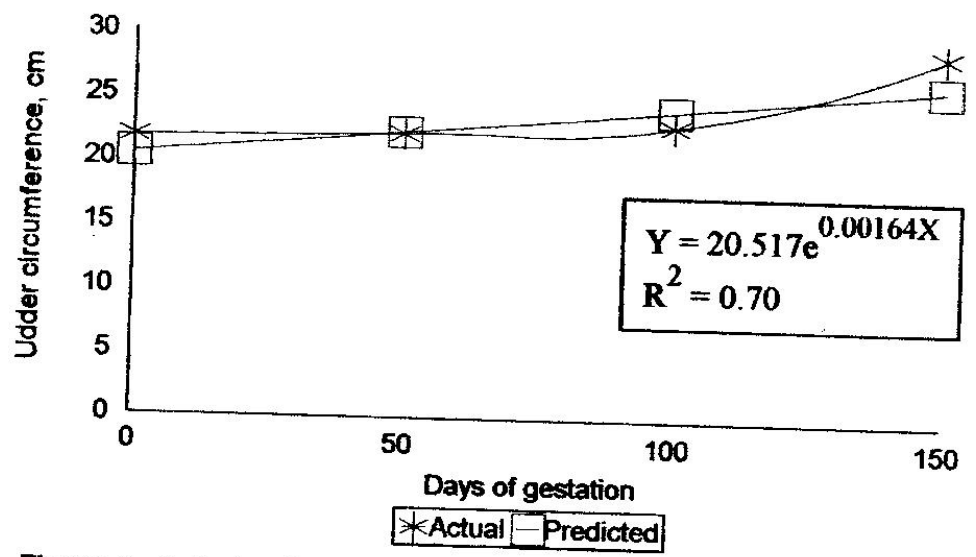

Figure 7 Actual and predicted values of udder circumference of West African Dwarf goats duing pregnancy 


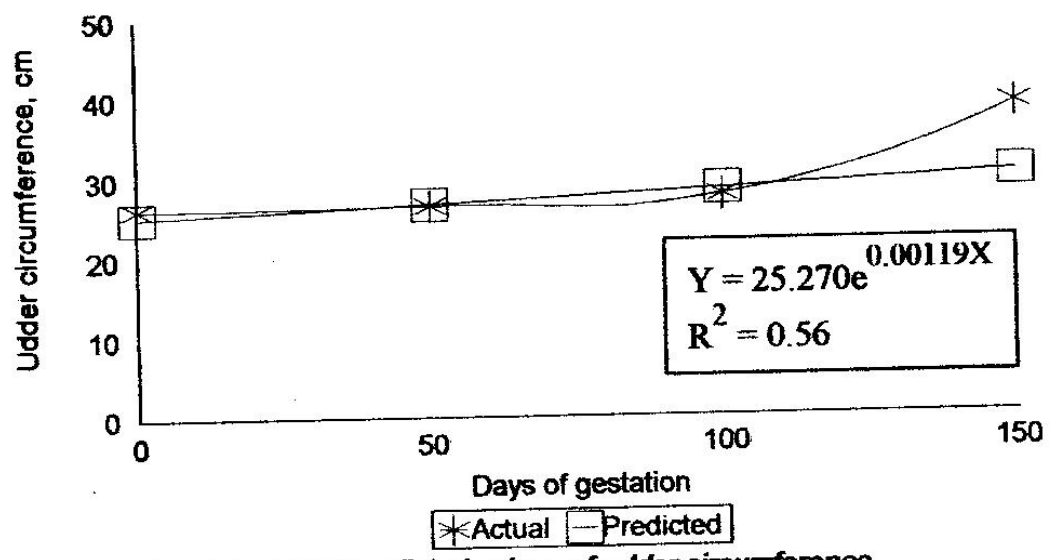

Figure 8 Actual and predicted values of udder circumference
of Red Sokoto goats during pregnancy

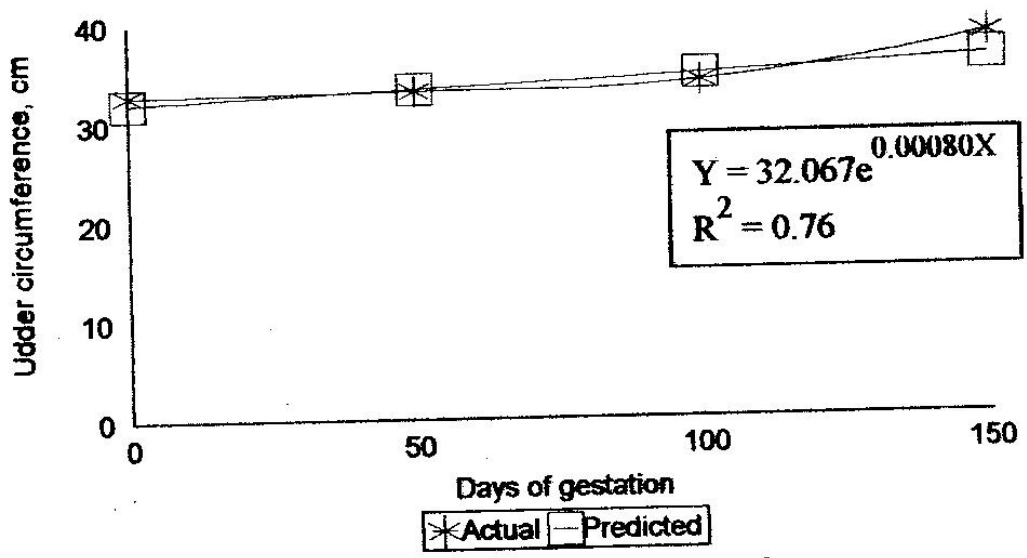

Figure 9 Actual and predicted values of udder circumference of Sahel goats during pregnancy 
Udder size of goats during pregnancy and its relationship with partial daily milk yield

Table 5 Correlations between udder growth parameters and average partial daily milk yield

\begin{tabular}{clc} 
& \multicolumn{1}{c}{$\mathrm{A}$} & $\mathrm{b}$ \\
\hline $\mathrm{b}$ & $-0.884^{* * *}$ & \\
PDM $^{2}$ & $0.795^{* *}$ & -0.608 \\
\hline
\end{tabular}

${ }^{* *} \mathrm{P}<0.01$ and ${ }^{* * *} \mathrm{P}<0.001$

${ }^{2}$ Average partial daily milk yield

Table 6 Phenotypic correlations between udder traits of goats during pregnancy

\begin{tabular}{llll}
\hline & $\mathrm{UW}$ & $\mathrm{UC}$ & $\mathrm{DBT}$ \\
\hline $\mathrm{UC}$ & $0.709^{* *}$ & & \\
$\mathrm{DBT}$ & $0.690^{* * *}$ & $0.790^{* * *}$ & $0.572^{*}$ \\
$\mathrm{TL}$ & 0.384 & $0.445^{*}$ \\
\hline \hline & "P $<0.05,{ }^{* *} \mathrm{P}<0.01$, and ${ }^{* * *} \mathrm{P}<0.001$ & \\
& 'See materials and methods for key to codes
\end{tabular}

because of the smaller size. This implies that the udder of WAD goats gets filled-up more quickly than the other breeds hence leading to the stoppage of milk secretion arising from negative feed-back mechanism which is controlled by hormones. The exponential function used for modeling udder growth during pregnancy achieved better fit for Sahel and WAD goats than for Red Sokoto goats as indicated by their $\mathrm{R}^{2}$ values i.e. Coefficient of determination (Figures $7-9$ ). This is expected because of the variations that exist in the pattern of udder growth among the three breeds during pregnancy which determines the nature of the data generated. The high positive phenotypic correlation between parameter $A$ and average PDM (Table 5) revealed that the size of udder at conception and during pregnancy could be an important factor in determining milk yield. Also, the high negative phenotypic correlation between parameter $A, b$ and average PDM (Table 5) revealed that the rate of increase of udder size during pregnancy is not so important to milk yield as the attainable udder size during pregnancy. This is so because if the rate of udder growth is high and the udder is small, the udder gets filled-up in-time thus leading to milk stoppage. However, if milking frequency (emptying the udder) is increased in the breed (WAD) with faster udder growth total milk production per lactation in that breed could be higher. Also, the high positive significant phenotypic correlations between UW, DBT, TL and UC (Table 6) observed were in consonance with findings of Amao (1999). This showed that the traits could be selected for milk production alongside with UC once the genetic basis is ascertained.

\section{Conclusion}

- Slight and substantial increases in udder dimensions of WAD, RS and Sahel goats occur during the first two trimester of pregnancy and the third trimester respectively.

- Sahel does had the largest udder dimensions with highest average PDM while WAD does had the smallest with the lowest average PDM.

- UW, DBT and TL were positively and highly correlated to UC. Thus indicating that if $U C$ is directly related to milk yield, they could also be selected for milk yield. 


\section{James and Osinowo}

- The size of udder at conception and during pregnancy could be a significant determinant of average PDM per lactation than the rate at which the udder size is attained.

- WAD does had the highest rate of udder growth during pregnancy than Red Sokoto and Sahel does thus suggesting higher proliferation of milksecreting cells in the udder and hence higher milk yield per lactation.

- The exponential function used for modeling udder growth during pregnancy achieved better fit in Sahel and WAD goats than in Red Sokoto goats.

\section{Acknowledgement}

The authors wish to thank the Chairman of Small Ruminant Technical Committee of Teaching and Research Farms of the University of Agriculture, Abeokuta and the personnel of the goat unit of the farm for their assistance.

\section{References}

Akpa, G.N., Duru, S., Dim, N.I., Alawa, J.P. and Jokthan, G.E. (1998): Sources of variations in udder traits of Red Sokoto goats. In: Oduguwa, O.O., Fanimo, A.O. and Osinowo, O.A. (eds). Animal Agriculture in West Africa: The sustainability question. Proc. Of the Silver Anniversary Conference of the Nig. Soc. For Anim. Prod. and the inaugural Conference of the West African Soc. For Anim. Prod. (WASAP) held at Gateway Hotel, Abeokuta, Nigeria, 21-. 26 March, 1998. Pp. 650.

Amao, O.A. (1999): Evaluation of udder traits in West African Dwarf and Red Sokoto goats. M. Agric. Dissertation. Department of Animal Production and Health, University of Agriculture, Abeokuta.
Anderson, R.R., Harness, J.R., Snead, A.F. and Salah, M.S. (1981): Mammary growth pattern in goats during pregnancy and lactation $J$. Dairy Sci. 64: 427 - 432 .

Dijkstra, J., France, J., Dhanoe, M.S., Maas, J.A., Hanigan, M.D., Rook, A.J. and Beever, E.D. (1997): A model to describe growth pattern of the mammary gland during pregnancy and lactation. J. Dairy of Sci. 80: 2340 - 2354.

Gomez, A.K. and Gomez, A.A. (1984): Statistical Procedures for Agricultural Research. 2nd Edition. John Wiley and Sons Inc. New York USA. Pp. 680.

James, I.J. (2000): Changes in udder traits of West African Dwarf, Red Sokoto and Sahel goats during pregnancy and lactation and their effects on partial daily milk yield. M. Agric. Dissertation. Department of Animal Production and Health, University of Agriculture, Abeokuta, Nigeria.

James, L.J. and Osinowo, O.A. 2002. Changes in Udder dimensions of West African Dwarf, Red Sokoto and Sahel goats during pregnancy and their relationship with partial daily milk yield. Proc. of the $27^{\text {th }}$ Ann. Conf. of Nig. Soc. For Anim. Prod. (NSAP), March 17-21, 2002, Fed. Univ. of Tech., Akure, Nigeria. Pp. $39-42$.

James, LJ., Osinowo, O.A., Ozoje, M.O., Biobaku, W.O. and Fanimo, A.O. 2002. Changes in Udder dimensions of West African Dwarf, Red Sokoto and Sahel goats during lactation and their phenotypic relationship with partial daily milk yield. Proc. of the $7^{\text {th }}$ Ann. Conf. of Anim. Sci Assoc. of Nig. (ASAN), September 16-19, 2002, Univ. of Agriculture, Abeokuta, Nigeria. Pp. $33-36$. 
Udder size of goats during iregnancy and its relationship with partial daily milk yield

Kinight, C.H. and Wilde, C.J. (1993): Mammary cell changes during pregnancy and lactation. Livest. Prod. Sci. 35:3.

Singh, R.P., Gupta, R. and Tomar, S.S. 1993. Udder shapes and their relation with milk production in crossbred cows. Indian $J$. Dairy Sci. $46(7): 289-291$.
Systat, (1993): Systat Computer Package. version 5.02. Systat, inc. 1800 Sherman Ave., Evanston, IL USA, 6021, 708.864 .5670 .

Tucker, H.A. (1987): Quantitaive estimates of mammary growth during various physiological stages: a review. J. Dairy. Sci. 70: $1958-1966$.

(Received 07 October 2002; Accepted 13 August 2003) 